\title{
Cryopreservation of Marine Unicellular Algae. I. A Survey of Algae with Regard to Size, Culture Age, Photosynthetic Activity and Chlorophyll-to- Cell Ratio
}

\author{
A. Ben-Amotz and A. Gilboa \\ Israel Oceanographíc \& Limnological Research, Tel-Shikmona, P.O.B. 8030, Haifa, Israel
}

\begin{abstract}
About a dozen species of marine unicellular algae were cultivated under constant growth conditions and tested for their ability to survive freezing in liquid nitrogen. All species survived uncontrolled direct freezing in liquid nitrogen poorly; however, the addition of a cryoprotective agent, dimethylsulfoxide (DMSO), and the application of a two-step cooling procedure enhanced the freezing resistance of most algae. Optimal conditions for two-step cooling were initial cooling in $5 \%$ dimethylsulfoxide to $-30^{\circ} \mathrm{C}$, then freezing in liquid nitrogen, and finally thawing at $30^{\circ} \mathrm{C}$. Freezing tolerance of viable algae was not related to culture age, photosynthetic activity or chlorophyll-to-cell ratio, but rather was specifically related to the algal species, and in a few cases to the algal size and to the specific growth rate. These observations indicate that the cryopreservation capability of unicellular marine algae is closely related to the intrinsic characteristics of the algae and to certain cellular properties of the cell.
\end{abstract}

\section{INTRODUCTION}

The process of freezing and freeze-drying has been applied to a variety of biological materials (Daily and Higgens, 1973; McGann and Farrant, 1976). The application of subfreezing temperatures as a means of longterm preservation of biological matrices depends upon developing a methodology that will ensure the survi$\mathrm{val}$ of the cells during the freezing process. There is a wide variation in methods regarding the conditions of optimal freezing of algae and techniques of their cryopreservation (Watanabe, 1959; Holm-Hansen, 1964; Hwang and Horneland, 1965; Hostetter and Hoshaw, 1970; Hwang and Huddock, 1971; Daily and Higgens, 1973; Takano et al., 1973; Tsuru, 1973; Schwarze, 1975; Hattano et al., 1976a, b; Morris, 1976a, b, c, 1978 ; Gresshoff, 1977; McGrath et al., 1978; Saks, 1978; Gilboa and Ben-Amotz, 1979). Optimal procedures for the cryopreservation of freshwater algae have been discussed in detail; however, methods for freezing and freeze-drying marine species are very limited. Tsuru (1973) and Saks (1978) reported on the cryopreservation of a limited number of marine algae by means of freezing in liquid nitrogen. McGrath et al. (1978) showed Iow viability of freeze-dried chlorophytes and chrysophytes. It seems that methods suitable for the freezing of bacteria, blue-green algae and freshwater algae give poor results when applied directly to marine algae, due to the complex interactions between the rate of cooling, formation of ice crystals, salt saturation, etc. (Farrant et al., 1977). Methods and optimum conditions needed during the freezing and freeze-drying procedures to ensure viable marine cells should, therefore, be determined empirically. The purpose of this communication is twofold: to survey freezing tolerance among a few marine unicellular algae, and to study methods of cryopreservation in relation to algal properties and growth parameters.

\section{MATERIALS AND METHODS}

\section{Cells}

Chlorella marina Butcher 211/27, C. ovalis Butcher 211/21a, C. salina Kufferath 211/25, C. spaerckii Alvik 211/29a, b, Nannochloris atomus Butcher 251/4a, N. oculata Droop 251/6, N. sarniensis 251/2, Nannochloris sp. 251/5, Phaeodactylum tricornutum Bohlin 1052/1a and Platymonas suecica (Kylin) Butcher 66/4 were 
obtained from the Culture Centre of Algae and Protozoa, Cambridge, England. Dunaliella salina was obtained from the collection of Dr. Thomas, La Jolla, Calif. USA.

\section{Growth Conditions}

Algae were cultivated on a sea water medium enriched with $5 \mathrm{mM} \mathrm{KNO}, 0.2 \mathrm{mM} \mathrm{KH}_{2} \mathrm{PO}_{4}, 1.5 \mu \mathrm{M}$ $\mathrm{FeCl}_{3}, 30 \mu \mathrm{M}$ EDTA, $5 \mathrm{mM} \mathrm{NaHCO}, 20 \mathrm{mM}$ Tris-Cl $\mathrm{pH}$ 7.5, $0.25 \mathrm{mM} \mathrm{Na} \mathrm{Na}_{2} \mathrm{SiO}_{3}$ and trace metal mix, (McLachlan, 1973). Cells were grown in liquid medium with shaking at $20^{\circ} \mathrm{C}$ under continuous illumination of white light fluorescent lamps at an intensity of 200 foot candles.

\section{Cooling, Freezing and Thawing}

Samples of 5 to $10 \mathrm{ml}$ of cells from liquid culture were centrifuged at $1500 \times \mathrm{g}$ for $5 \mathrm{~min}$ in a plastic conical tube. The pellet was treated by one of the following procedures: (a) uncontrolled direct freezing in liquid nitrogen and storage at the same temperature; (b) one-step cooling technique (Tsuru, 1973) in which incubation at room temperature (about $20^{\circ} \mathrm{C}$ ) for 15 to 30 min with DMSO preceded a fast cooling in liquid nitrogen; (c) two-step technique (Morris, 1976a, b, 1978) in which a suspension of concentrated algae was incubated with dimethylsulfoxide (DMSO) for 15 to 20 min at $20^{\circ} \mathrm{C}$, then transferred into a cooling bath at $-30^{\circ} \mathrm{C}$ for $15 \mathrm{~min}$, and finally fast-cooled in liquid nitrogen. After storage in the subzero holding temper- ature, the algae were thawed by agitation in a water bath at $30^{\circ} \mathrm{C}$ until the ice crystals disappeared.

\section{Viability Assays}

Assay of viability of cells after cryopreservation was either by colony formation, (Morris, 1976a, b, 1978), or by oxygen evolution, (Gilboa and Ben-Amotz, 1979).

\section{Growth Measurements}

Cell counting was achieved by microscopic counting (Guillard, 1973). Chlorophyll was estimated spectrophotometrically after pigment extraction with $80 \%$ acetone or $90 \%$ methanol (Jensen, 1978). Cell size was measured microscopically with a micrometer.

\section{RESULTS}

\section{Algae Survey and Growth Characteristics}

Prior to freezing, studies were conducted to survey a dozen unicellular marine algae for their growth properties (Table 1). Growth was measured under constant environmental conditions and was expressed as $\log N$ / No $=\mu \mathrm{t}$. The specific growth rate $\left(\mu \mathrm{d}^{-1}\right)$ and the maximal concentration of cells per $\mathrm{ml}$ were obtained from the logarithmic and the stationary phases of growth, respectively. In general, large cells show low specific growth and high concentration of cells, and small cells vice versa.

Table 1. Characteristics of various unicellular marine algae. Cells were grown on enriched sea water at $20^{\circ} \mathrm{C}$ with shaking. Cell size was estimated microscopically in mid-logarithmic grown cells. A specific growth rate of 2 represents doubling of the algae every $24 \mathrm{~h}$

\begin{tabular}{|lccc|}
\hline Species & $\begin{array}{c}\text { Cell size } \\
\text { (length } \mu \mathrm{m} \times \text { width } \mu \mathrm{m})\end{array}$ & $\begin{array}{c}\text { Specific growth rate } \\
\left(\mu \mathrm{d}^{-1}\right)\end{array}$ & $\begin{array}{c}\text { Maximal concentration } \\
\left(\text { cells } \mathrm{m}^{-1}\right)\end{array}$ \\
\hline Chlorella marina & $10 \times 8$ & 2.0 & $1.0 \times 10^{7}$ \\
Chlorella ovalis & $10 \times 8$ & 1.8 & $1.0 \times 10^{7}$ \\
Chlorella salina & $8 \times 6$ & 2.0 & $8.0 \times 10^{6}$ \\
Chlorella spaerckii & $2 \times 2$ & 2.7 & $4.0 \times 10^{7}$ \\
Chlorella spaerckij & $2 \times 2$ & 2.8 & $2.0 \times 10^{7}$ \\
Dunaliella salina & $8 \times 6$ & 2.1 & $2.0 \times 10^{7}$ \\
Nannochloris atomus & $2 \times 2$ & 2.5 & $6.0 \times 10^{7}$ \\
Nannochloris oculata & $2 \times 2$ & 2.5 & $5.0 \times 10^{7}$ \\
Nannochloris samiensis & $2 \times 2$ & 2.2 & $3.5 \times 10^{7}$ \\
Nannochloris sp. & $2 \times 2$ & 2.2 & $3.0 \times 10^{7}$ \\
Phaeodactylum tricornutum & $32 \times 3$ & 2.3 & $3.0 \times 10^{7}$ \\
Platymonas suecica & $15 \times 10$ & 1.7 & $1.0 \times 10^{7}$ \\
\hline
\end{tabular}




\section{Optimal Freezing Procedure}

Table 2 illustrates a comparison of exposing the cells to 3 procedures of freezing in liquid nitrogen. Direct freezing of algae in liquid nitrogen resulted in a severe loss of viability. Applying the method of Tsuru (1973), which includes pretreatment of the algae with $5 \%$ DMSO at $20^{\circ} \mathrm{C}$, increases the survival of most algae significantly. However, optimal recovery of algae exposed to liquid nitrogen was obtained by applying the two-step technique (Morris, 1976a, b, 1978) to the marine algae. Algae were initially incubated at around
$20{ }^{\circ} \mathrm{C}$ with $5 \%$ DMSO, then were transferred into $-30^{\circ} \mathrm{C}$ for $15 \mathrm{~min}$, allowing thermal and osmotic equilibrium between the cells and the medium, and finally were frozen in liquid nitrogen. It is apparent that protection of cell integrity and viability occurs in cells equilibrated in steps to freezing in DMSO. Of the 12 species tested, the large strains of Chlorella, $C$. salina, C. ovalis and C. marina, resisted freezing better than the other algae. Since the culturing conditions and the growth medium were identical for all species, the tolerance of algae to freezing may reflect a natural inherent property which is not reflected in the growth conditions.

Table 2. Effect of different freezing techniques in liquid nitrogen on algal recovery. Algae were grown autotrophically on enriched sea water

\begin{tabular}{|c|c|c|c|}
\hline Species & $\begin{array}{l}\text { Direct } \\
\text { freezing in liquid } \mathrm{N}_{2}\end{array}$ & $\begin{array}{l}\text { iability }(\% \text { of control) } \\
\text { One-step } \\
\text { freezing technique }\end{array}$ & $\begin{array}{c}\text { Two-step } \\
\text { freezing technique } \ldots\end{array}$ \\
\hline Chlorella marina & 8 & 52.2 & 82.2 \\
\hline Chlorella ovalis & 6 & 64.4 & 86.1 \\
\hline Chlorella salina & 4 & 53.2 & 87.1 \\
\hline Chlorella spaerckii a & 3 & 64.3 & 72.2 \\
\hline Chlorella spaerckii b & 2 & 62.8 & 72.1 \\
\hline Dunaliella salina & 0 & 8.2 & 27.2 \\
\hline Nannochloris atomus & 3 & 25.5 & 54.2 \\
\hline Nannochloris oculata & 8 & 52.1 & 63.1 \\
\hline Nannochloris sarniensis & 2 & 0 & 34.3 \\
\hline Nannochloris sp. & 0 & 51.5 & 31.2 \\
\hline Phaeodactylum tricornutum & 0 & 5.0 & 29.1 \\
\hline Platymonas suecica & 0 & 8.6 & 20.0 \\
\hline \multicolumn{4}{|c|}{$\begin{array}{l}\text { Cells from the late logarithmic phase of culture }\left(8-16 \mathrm{~d} \text { at } 20^{\circ} \mathrm{C}\right) \text { were frozen by one of the following techniques: " cells frozer } \\
\text { directly in liquid nitrogen; } \cdot \text { cells resuspended in } 5 \% \text { DMSO at } 20^{\circ} \mathrm{C} \text { for } 15 \mathrm{~min} \text { and then frozen in liquid nitrogen; } \cdots \text { cell } \\
\text { resuspended in } 5 \% \text { DMSO at } 20^{\circ} \mathrm{C} \text { for } 15 \mathrm{~min} \text {, then cooled at }-30^{\circ} \mathrm{C} \text { for } 15 \mathrm{~min} \text {, and finally frozen in liquid nitrogen. Fo } \\
\text { further details, see 'Materiais and Methods'. }\end{array}$} \\
\hline
\end{tabular}

Table 3. Chlorophyll content and viability of algae from logarithmic and stationary phases of growth. Algae grown on enriched sea water were assayed for chlorophyll and viability at the logarithmic phase (2-15 d) and the stationary phase (15-35 d). Freezing was in liquid nitrogen without cryoprotectant

\begin{tabular}{|c|c|c|c|c|}
\hline \multirow[t]{3}{*}{ Species } & \multicolumn{2}{|c|}{ Chlorophyll content } & \multicolumn{2}{|c|}{ Viability } \\
\hline & $\begin{array}{c}\text { Logarithmic } \\
\text { phase }\end{array}$ & $\begin{array}{l}\text { Stationary } \\
\text { phase }\end{array}$ & $\begin{array}{c}\text { Logarithmic } \\
\text { phase }\end{array}$ & $\begin{array}{c}\text { Stationary } \\
\text { phase }\end{array}$ \\
\hline & \multicolumn{2}{|c|}{ pg Chl cell ${ }^{-1}$} & \multicolumn{2}{|c|}{$\%$ of control } \\
\hline Chlorella marina & 2.0 & 1.5 & 2 & 2 \\
\hline Chlorella ovalis & 1.5 & 1.2 & 4 & 3 \\
\hline Chlorella salina & 1.0 & 1.0 & 5 & 4 \\
\hline Chlorella spaerckii a & 0.25 & 0.20 & 3 & 3 \\
\hline Chlorella spaerckii b & 0.2 & 0.18 & 2 & 2 \\
\hline Dunaliella salina & 2.0 & 1.5 & 0 & 0 \\
\hline Nannochloris atomus & 0.30 & 0.2 & 3 & 1 \\
\hline Nannochloris oculata & 0.35 & 0.3 & 2 & 3 \\
\hline Nannochloris samiensis & 0.35 & 0.3 & 2 & 2 \\
\hline Nannochloris sp. & 0.25 & 0.25 & 0 & 0 \\
\hline Phaeodactylum tricornutum & 0.13 & 0.13 & 0 & 0 \\
\hline Platymonas suecica & 1.7 & 1.7 & 0 & 0 \\
\hline
\end{tabular}




\section{Effect of Culture Age}

Previous studies (Morris, 1978) showed that the cellular tolerance to freezing of freshwater Chlorella increases with culture age, reaching a maximum in the late stationary phase. To determine whether this is a general phenomenon, logarithmic and stationary phase cultures of a number of marine algal strains were frozen in the absence of DMSO and the viability was compared with the chlorophyll content of the algae (Table 3). With most species, chlorophyll-to-cell ratio was lower in stationary phase cells than in young cells; however, in contrast to the chlorophyll variations, the viability of the algae was not affected by the culture age and remained low irrespective of culture phase. Moreover, similar to the decrease of cell chlorophyll in the stationary phase, the photosynthetic oxygen evolution measured in pmoles $\mathrm{O}_{2}$ cell $^{-1} \mathrm{~h}^{-1}$ also decreased with culture age (Fig. 1); however, neither of these could be correlated with freezing tolerance. It is clear, therefore, that the capability of an alga to resist freezing is not affected by cell variations during growth, but rather originates from intrinsic algal characteristics.

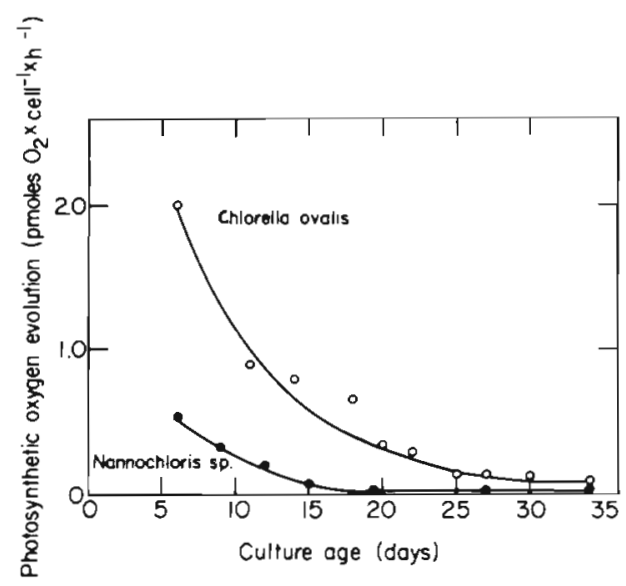

Fig. 1. Chlorella ovalis and Nannochloris sp. Effect of culture age on photosynthetic oxygen evolution. Algae were grown autotrophically on enriched sea water. Photosynthetic oxygen evolution was measured with an oxygen electrode, and cells were counted microscopically with a hemacytometer on the days indicated

\section{DISCUSSION AND CONCLUSIONS}

The reasons for the differences among cells exposed to freezing lie first in their particular sensitivity to shrinkage and swelling under hypertonic and hypotonic conditions, respectively, in the process of freezing (Farrant et al,, 1977). Second, the permeability of cells to water and their surface-to-volume ratio determine the rate of cooling at which shrinkage is prevented and intracellular ice forms. The cellular injury of volume changes associated with ice crystalization and salt accumulation is more significant in marine algae than in freshwater algae. Optimal conditions of survival were practically experimented with each species of the unicellular marine algae. Our comparative evaluation of freezing tolerance among these algae showed significant differences which could not be attributed to either the growth conditions or the culture age. A few algae possess a natural capability to survive freezing better than the others. The nature of freezing tolerance is not yet clear, but the ability of certain algae to survive at frost temperature suggests that those algae have developed a cellular mechanism of freezing protection. It seems reasonable to assume, therefore, that resistance to freezing is closely related to the intrinsic characteristics of the algae and to certain cellular properties of the cell.

The introduction of the two-step cooling technique (McGann and Farrant, 1976) enabled us to overcome the difficulties of direct freezing and to store marine algae successfully in liquid nitrogen. In this method, the permanent cryoprotective agent, DMSO, increases cellular survival by cell penetration and reduction of the hypertonic osmotic effects of cooling. Because a proportion of the impermeant extracellular solute was replaced by the permeant DMSO, less shrinkage occurred and the damage to the cell was minimal. Significant differences among the algae in cell viability following the two-step cooling technique and lack of correlation with culture age, chlorophyll-to-cell ratio and photosynthetic activity indicate that membrane properties and/or physico-osmotic causes may contribute to cold hardening. The above results are in agreement with the general assumption that the primary site of injury to cells following freezing and thawing is the cell membrane (Mazur, 1970). Differences in freezing injury among the marine algae may, therefore, reflect different properties and compositions of the algal membranes.

Acknowledgements. This study was supported by a grant from the National Council for Research and Development, Isreal, and the GKSS Geesthacht-Tesperhude, Federal Republic of Germany.

\section{LITERATURE CITED}

Daily, W. A., Higgens, C. E. (1973). Preservation and storage of microorganisms in the gas phase of liquid nitrogen. Cryobiology 10: 364-367

Farrant, J., Walter, C. A., Lee, H., Morris, G. J., Clarke, K. J. (1977). Structural and functional aspects of biological freezing techniques. J. Microscopy 111: 17-34

Gilboa, A., Ben-Amotz, A. (1979). An improved method for rapid assaying of viability of cryopreserved unicellular algae. Pl. Sci. Lett. 14: 317-320

Gresshoff, P. M. (1977). Chlamydomonas reinhardii, a model plant system. II. Cryopreservation. Pl. Sci. Lett. 9: 23-25 
Guillard, R. R. L. (1973). Division rates. In: Stein, J. R. (ed.) Phycological methods. Cambridge University Press, London, pp. 289-311

Hattano, S., Sadakane, H., Tutumi, M., Watanabe, $\Upsilon$ (1976a). Studies on frost hardiness in Chlorella ellipsoidea. I. Development of frost hardiness of Chlorella ellipsoidea in synchronous culture. Pl. Cell Physiol., Tokyo 17: 451-458

Hattano, S., Sadakane, H., Tutumi, M., Watanabe, T (1976b). Studies on frost hardiness in Chlorella ellipsoidea. II Effect of inhibitors of RNA and protein synthesis and surfactants on the process of hardening. Pl. Cell Physiol. Tokyo 17: 643-651

Holm-Hansen, O. (1964). Viability of lyophilized algae. Can. J. Bot. 42: 127-137

Hostetter, H. P., Hoshaw, R. W. (1970). Environmental factors affecting resistance to desiccation in the diatom Stauroneis anceps. Am. J. Bot. 57: 512-518

Hwang, S. W., Horneland, W. (1965). Survival of algal cultures after freezing by controlled and uncontrolled cooling. Cryobiology 1: 305-311

Hwang, S. W., Huddock, G. A. (1971). Stability of Chlamydomonas reinhardii in liquid nitrogen storage. J. Phycol. 7: $300-303$

Jensen, A. (1978). Chlorophyll and carotenoids. In: Hellebust, J. A., Craigie, J. S. (eds) Physiological and biochemical methods. Cambridge University Press, London, pp. 59-70

Mazur, P. (1970). Cryobiology: the freezing of biological systems. Science, N.Y. 168: 939-946

McGann, L. E., Farrant, J. (1976). Survival of tissue culture cells frozen by twostep procedures to $-196^{\circ} \mathrm{C}$. 2 . Warming rate and concentration of dimethylsulfoxide. Cryobiology 13: $269-273$
McGrath, M. S., Daggett, P. M., Dilworth, S. (1978). Freezedrying of algae: Chlorophyta and Chrysophyta. J. Phycol. $14: 521-525$

McLachlan, J. (1973). Growth media - marine. In: Stein, J. R. (ed.) Phycological methods. Cambridge University Press, London, pp. 25-51

Morris, G. J. (1976a). Effect of growth temperature on the cryopreservation of Prototheca. J. gen. Microbiol. 94: 395-399

Morris, G. J. (1976b). The cryopreservation of Chlorella. I. Interactions of rate of cooling, protective, additive and warming rate. Arch. Microbiol. 107: 57-62

Morris, G. J. (1976c). The cryopreservation of Chlorella. II. Effect of growth temperature of freezing tolerance. Arch. Microbiol. 107: 309-312

Morris, G. J. (1978). Cryopreservation of 250 strains of chlorococcales by the method of two-step cooling. $\mathrm{Br}$. Phycol. J. 13: 15-24

Saks, N. M. (1978). The preservation of salt marsh algae by controlled liquid nitrogen storage. Cryobiology 15: 563-568

Schwarze, P. (1975). Observation on the cold resistance of Chlorella vulgaris. Biochem. Physiol. Pflanzen 167: 353-355

Takano, M., Sado, J., Ogawa, T., Terui, G. (1973). Freezing and freeze-drying of Spirulina platensis. Cryobiology 10: $440-444$

Tsuru, S. (1973). Preservation of marine and freshwater algae by means of freezing and freeze-drying. Cryobiology 10 : $445-452$

Watanabe, A. (1959). Some devices for preserving blue-green algae in viable state. J. appl. Microbiol. 5: 153-157 